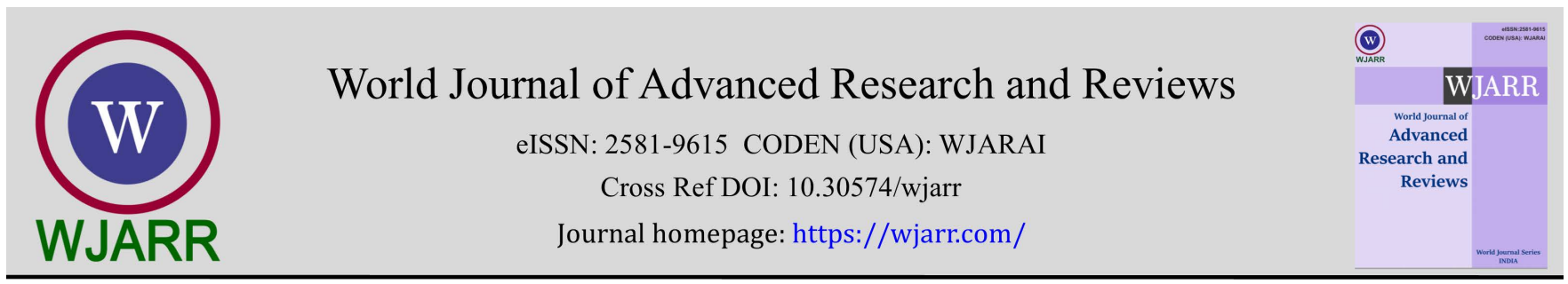

(REVIEW ARTICLE)

\title{
Glial cells: More than just a silent disciple of neural system
}

\author{
Pranav Gupta *, Sarabjot Singh and Sarthak Khurana \\ Department of Pharmaceutical Sciences, School of Pharmacy, Delhi Pharmaceutical Sciences and Research University, \\ New Delhi, India.
}

World Journal of Advanced Research and Reviews, 2021, 09(01), 212-221

Publication history: Received on 04 January 2021; revised on 11 January 2021; accepted on 13 January 2021

Article DOI: https://doi.org/10.30574/wjarr.2021.9.1.0010

\begin{abstract}
The dominant focus of neuroscience has long been neurons and synapses; thus, under the neuronal doctrine, the pathophysiology of psychiatric disorders has come to be recognized, ignoring other types of CNS cells. Many cells, including neurons and glial cells, make up our brain: astrocytes, oligodendrocytes, NG2 cells, microglia and ependyma. Neurons were known to be the brain's basic information processing unit, so much of the neurological research was based solely on neurons. Recent research, however, show that glial cells are far more than just the "glue" binding the CNS neurons together. Glial cells provide neurons with support functions and they are much more numerous than neurons. A novel theory has shown that glial and neurons can talk and understand the same chemical language, so glial cell dysfunction results in abnormal neuro - glial interactions, which in turn impairs neuronal cell functionality. It can shed new light on the explanation of several mysterious aspects by digging up the glial functions and further comprehension of these vital cells, and the interaction between neurons and glial.
\end{abstract}

The current situation and new findings related to the CNS glial and their role in the neural network are briefly reviewed.

Keywords: Neuroinflammation; NTF; BDNF; NGF-Mice Model; Stroke; Oligodendrogenesis

\section{Introduction}

In the central nervous system (CNS), glial cells are the most abundant cell type and play an important role in maintaining brain homeostasis, forming myelin and providing neuron support and defense, etc.

Generally, the word neuroglia is translated as nerve glue. This has been used in the recent past to characterize passive structural cells. This view has currently been questioned and the actual complex and multifunctional existence of neuroglia is beginning to be understood.

Neuroglia [1] is sub classified into central nervous system (CNS) glial and peripheral nervous system glial (PNS). CNS glial includes astrocytes, microglia, oligodendrocytes, and NG2-glia (also known as polydendrocytes).

Astrocytes are the most common type of cell in the human brain, contributing to brain homeostasis through neuronal metabolism control, CNS inflammation modulation, and direct/indirect synaptic transmission such as MNDA receptors $[2,3]$. For different neurological disorders, astrocyte dysfunction has been important [4]. Recent studies have demonstrated irregular expression in the postmortem brain of patients with schizophrenia and significant affective disorders of glial fibrillary acid protein (GFAP) - a prototypical astrocyte marker [5-7]. Moreover, recent rodent studies have indicated that anxious and depressed behaviors are modulated by astrocytes [8, 9]. On the other hand,

\footnotetext{
* Corresponding author: Pranav Gupta

Department of Pharmaceutical Sciences, School of Pharmacy, Delhi Pharmaceutical Sciences and Research University, New Delhi, India.

Copyright (@ 2021 Author(s) retain the copyright of this article. This article is published under the terms of the Creative Commons Attribution Liscense 4.0.
} 
antidepressant direct modulating effects have also been revealed [10-13]. Astrocytes are also expected to be a novel therapeutic target for different psychiatric conditions, such as major affective disorders and bipolar disorders [14, 15].

Via formulating myelin around axons, oligodendrocytes contribute to brain growth and homeostasis in the brain, promoting neuronal networks in the brain. New oligodendrocyte functions, such as the monitoring of neuronal activities through myelin-forming oligodendrocytes [16] and the modulation of the conduction velocity of action potentials along axons in the rat hippocampus [17], have recently been established. Oligodendrocyte dysfunctions have been reported from a series of genetic studies [18, 19], postmortem studies [20-22], and diffusion tensor imaging (DTI) studies [2327] in psychiatric disorders, in particular schizophrenia and major affective disorders.

Microglia are special mesodermal glial cells that function as 'brain macrophages' in the brain; immunological/inflammatory actors pass around and release cytokines and free radicals [28, 29]. Via inducing inflammation and oxidative stress, microglia have thus shown to play an important role in various brain pathologies, such as neurodegenerative diseases and neuropathic pain [30-32]. Lifelong oligodendrocyte precursors function as NG2-glia.

PNS neuroglia include (a) Schwann cells (additionally subdivided into three: myelinated Schwann cells covering myelincontaining axons; non-myelinated Schwann cells covering non-myelinated Schwann cells and perisynaptic Schwann cells covering neuromuscular junctions; (b) satellite glial cells protecting peripheral ganglion neurons; (c) olfactory glial cells; and (d) enteric glial.

CNS and PNS neuroglia, together, are important for normal bodily function in the broadest sense.

\section{Impact of stroke on astrocytes}

Throughout the central nervous system (CNS), astrocytes weave their processes, assisting and defending fragile neurons through the regulation of cerebral blood flow, cerebral metabolism, and neurotransmission [33, 34]. The backbone of glial limitans, the unique blood-brain barrier (BBB) that sequesters the CNS away from the rest of the body, is also formed by astrocytes [35]. The role of astrocytes in stroke pathology after a brain injury such as ischemic stroke is complex, with evidence showing both beneficial and deleterious roles of astrocytes [36-40]. Astrocytes react robustly following CNS insults, releasing proinflammatory mediators that recruit immune cells and initiate glial scar formation to contain the injury area and restore the integrity of the BBB [35]. Nothing is currently understood, however, about the interactions between astrocytes and the peripheral immune system following brain injury. Li et al. [41] report in PNAS that IL-15 derived from astrocytes is a major driver of tissue damage and poor outcome after cerebral ischemia, an effect that depends on IL-15's ability to specifically improve the activation and cytotoxic effecter functions of natural killer (NK) cells and CD8+ T lymphocytes (Fig. 1).

Li et al. [41] identified IL-15 as one of the factors produced in large quantities by astrocytes isolated from the brains of mice 24 hours after stroke using proteomic profiler array analysis. The Li et al. [41] study is the first to show that after ischemic stroke, astrocytes are a major source of IL-15 in the CNS. Li et al. transgenically engineered mice to specifically over express IL-15 in astrocytes to establish the function of IL-15 in stroke pathology. Although these mice displayed no enhanced neuroinflammation under normal conditions, tissue damage and neurological impairment after experimental ischemic stroke were aggravated by over expression of astrocytic IL-15 in transgenic animals. A complementary analysis using IL-15 in vivo lentiviral knockdown in wild-type mice astrocytes resulted in decreased tissue damage and improved neurological results, providing more evidence that IL-15 derived from astrocytes aggravates the pathology of ischemic stroke. 


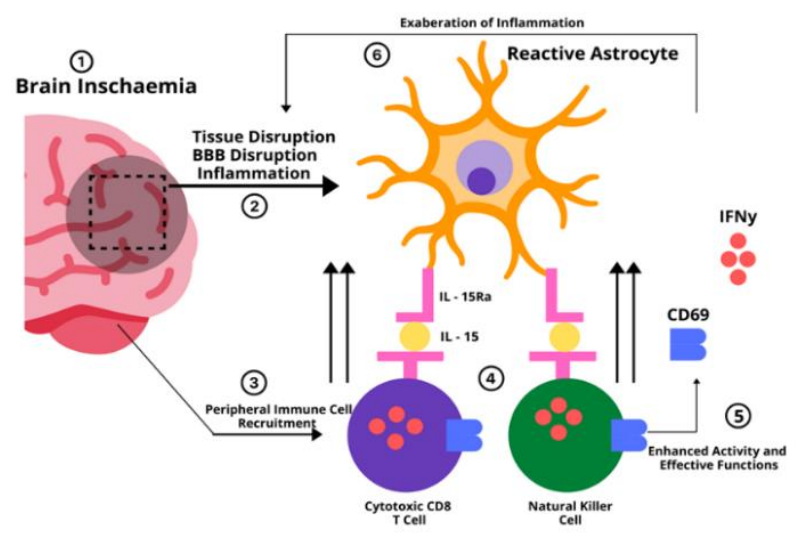

Figure 1 Astrocytes up- regulate IL-15 in response to inflammatory signals released by dying cell following ischemia. Before being transported to the membrane surface, IL-15 complexes with IL-15R alpha are recognized by (infiltrating NK cells and CD8+ lymphocytes, resulting in their activation (CD69 expression) and $\mathrm{u}$ - regulation (including IFN-y production) of their cytotoxic effector functions, leading to cell-mediated immunity and further exacerbating brain inflammation from astrocytes aggravates the pathology of ischemic stroke [68].

IL-15 is considered to peripherally play a crucial role in the maintenance and functioning of immune cells, including NK and T lymphocytes [42, 43]. Li et al. [41] show that over expression of IL-15 in astrocytes led to increased penetration into the brain after stroke of NK and CD8+ T lymphocytes. Importantly, no alterations were found in other infiltrating peripheral immune cells or altered microglial polarization. The deleterious effects of astrocyte IL-15 over expression in transgenic animals were alleviated by in vivo depletion of CD8+ T cells, NK cells, or both.

Subsequent studies have shown that astrocyte derived IL-15 improves the expression of the molecules required for their activation and cytotoxicity, including CD69 and IFN- $\gamma$, in NK and CD8+ T cells. These results indicate that astrocytic IL-15 is a regulator of lymphocyte activation and cytotoxicity in the CNS following injury, along with previous studies showing that NK and CD8+ T lymphocytes worsen tissue damage after ischemic stroke [41].

\section{Neuroinflammation}

Neuroinflammation is the neural tissue's complex innate immune response to restrain infection and generically remove bacteria, cell debris, and misfolded proteins. Neuroinflammation initially plays a role in neural tissue fixation and resolution as an integral component of CNS innate immunity. However, neuroinflammation becomes recurrent and harmful to neuronal cells in chronic neurological diseases. Accumulating evidence indicates that one of the most common pathologies in CNS diseases is neuroinflammation. Inflammatory reaction in the CNS is the product of all glial cells contributing to the cumulative impact. Neuroinflammation, however, is different from inflammation in peripheral tissues. This disparity is primarily due to the types of cells involved and how they interact with each other [44]. No wonder, therefore, that the dynamic interplay between neuroimmunology and CNS diseases has sparked considerable interest in recent years.

\section{Initiation of inflammation in cns}

The most motile cell in the CNS is microglia, the resident innate immune cell within the CNS. There are highly active microglial processes. Also, in the resting state, they continuously search the parenchyma microenvironment [45]. In harmful stimuli or abnormal states of the CNS, they are often triggered earlier than other glial cells [46]. Therefore, they often serve as the first violin or play the sonata part of the CNS inflammation symphonies' beginning motion.

The most abundant cell type in the CNS is astrocytes. Their reactions to inflammatory stimuli, however, appear more passive than microglia [47]. Microglia was once known to be involved in the first line of protection and neuroinflammation by transmitting immune signals to astrocytes where the signals are eventually amplified and propagated. However, as astrocytes have close contact with neurons and capillary vessels, astrocytes are known to control neuron metabolism. In the CNS environment, for instance, astrocytes are essential regulators of ions and neurotransmitters [48]. Astrocytes can also be known to show active parts in the initiation of inflammation in this respect. 
Due to their high metabolic needs, oligodendrocytes are vulnerable to different insults [49]. In addition, close communication with resident immune cells between cells derived from an oligodendrocyte lineage implies the role of oligodendrocytes in triggering neuroinflammation caused by anti-myelin immunity diseases [50]. Therefore, its unique characteristics and the nature of the inflammatory signals determine the specific role of each type of glial cell involved in initiating various types of neuroinflammation.

\section{Escalation of inflammation in cns}

Reactive glial cells secrete abundant pro-inflammatory mediators during the development of inflammation to engage in the opening of the BBB and recruit peripheral blood immune cells to penetrate into the parenchyma of the CNS and clean up pathogens or damaged tissue debris. At the same time, to protect tissues from inflammatory signals determine the specific role of each type of glial cell involved in initiating various types of neuroinflammation.

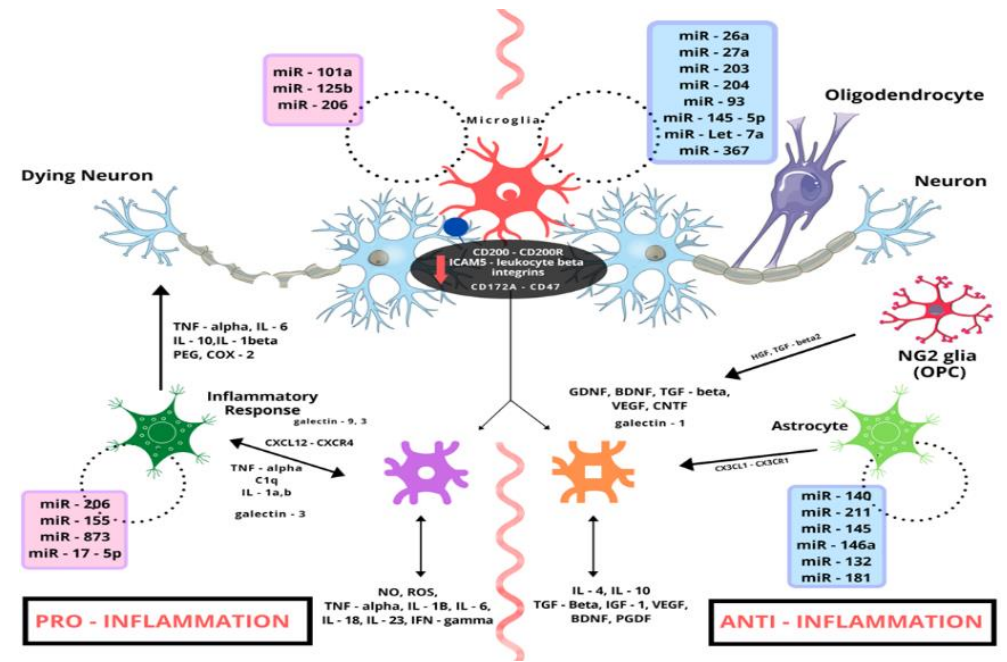

Figure 2 Pro-inflammatory mediators of pro-inflammatory microglia (TNF- $\alpha$, IL-6, IL-1 $\beta$, IL-18, IL-23, IFN- $\gamma$, NO, and ROS) [69].

\section{Escalation of inflammation in cns}

Reactive glial cells secrete abundant pro-inflammatory mediators during the development of inflammation to engage in the opening of the BBB and recruit peripheral blood immune cells to penetrate into the parenchyma of the CNS and clean up pathogens or damaged tissue debris. At the same time, to protect tissues from secondary damage caused by over activation of inflammation, the responses of glial cells and immune cells are coordinated. Both pro-and antiinflammatory responses can be stimulated simultaneously once the cascade is triggered. Glial cells may exhibit various functions to deteriorate or mitigate tissue damage in this process. The different phenotypes of glial cells and their interactions with each other determine the "two-sided" character of neuroinflammation. Understanding the underlying mechanisms would be instrumental in intervening in the production of CNS diseases.

According to fig. 2, 'Two-sided' glial cell features and the pro-anti-inflammation equilibrium in the progression of CNS neuroinflammation. In the development of neuroinflammation, activated glial cells grow into two classes of counteracting phenotypes:

Secretion of pro-inflammatory mediators of pro-inflammatory microglia (TNF- $\alpha$, IL-6, IL-1 $\beta$, IL-18, IL-23, IFN- $\gamma$, NO, and ROS) and pro-inflammatory mediators facilitate toxic microglia differentiation. Secreted by activated microglia, cytokines (IL-1 alpha/ $\beta$, TNF-alpha, and C1q) induce toxic astrocytes that lead to neuronal and oligodendrocyte death. In cellular debris clearance and tissue repair, the anti-inflammatory mediators (IL-4, IL-10, TGF- $\beta$, IGF- 1 , VEGF, BDNF, and PDGF) of protective microglia are involved. Regulation of the pro-/anti-inflammation balance between cells of the neuron and glial:

(a) Pro- and anti-inflammation target signaling pathways for intracellular inflammation and form positive/negative feedback loops to promote/suppress the development of pro-inflammatory factors in microglia and astrocytes. 
(b) Inflammation-inhibiting pathways of contact-dependent signaling activity between neurons and microglia (CD200CD200R, CD22-CD45, CD172A-CD47, ICAM5-leukocyte, and $\beta 2$-integrins) minimize inflammation processes.

(c) Paracrine soluble factor signaling pathways include chemokines (CXCL12-CXCR4, CX3CL1-CX3CR1 axis), neurotrophic factors (GDNF, BDNF, TGF- $\beta$, VEGF, CNTF, and HGF), and other secreted proteins among different glial cell groups (galectin-1, 3, 9).

\section{Components affecting glial cells}

The fate of OLGs and myelination of neurons in the CNS is the most studied glial phenotype in NTF-deficient mice. To become capable of myelinating neuronal populations, OLGs distinguish from OPCs [51]. Multiple factors [52] involving many NTFs depend on their survival, maturation and functionality. It has been documented that neurotrophins and CNTF family ligands contribute to the proliferation, migration, maturation, survival and myelination abilities of OLGs and their precursors. Except NGFs, studies using different KO mice have advocated the presence of these NTFs. Homozygous NGF-KO mice pose challenge not only in vivo but also in vitro early developmental stages [53]. Other in vivo and in vitro studies, however, support the participation of NGF in the promotion of OPC proliferation and migration [54].

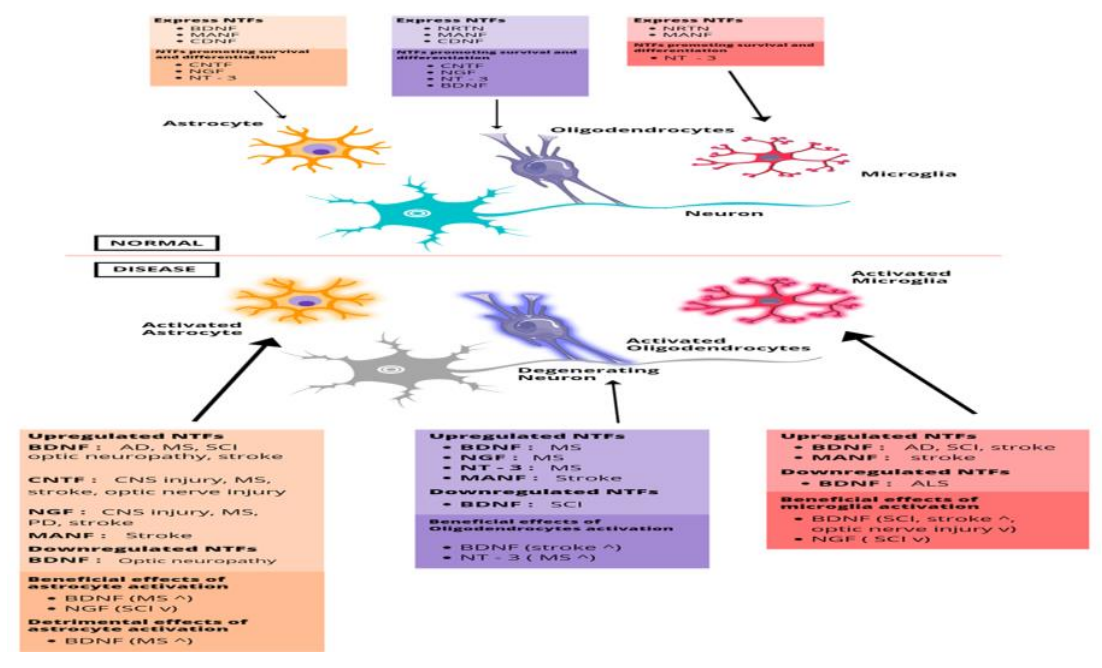

Figure 3 In normal and disease situations, expression of NTFs in glial cells and their effects on survival, differentiation, and activation of glial. MS, multiple sclerosis; AD, Alzheimer's disease; ALS, amyotrophic lateral sclerosis; PD, Parkinson's disease; SCI, spinal cord injury [70].

The neurotrophic factor and NT-3 derived from the brain have also been shown to contribute to oligodendrogenesis in the CNS. An early research analysis by McTigueetal. (1998) showed that oligodendrogenesis following CNS injury was promoted by neuronal grafts with either NT-3 or BDNF. In addition, deprivation of either resulted in decreased OPC amounts, and decreased CNS neuron myelination. In the basal forebrain, both homozygous and heterozygous BDNFKOs had less NG2-positive OPCs, and decreased myelin protein levels were observed in homozygous animals throughout growth.

Several studies indicate that CNTF also plays an important role in the maturation, proliferation, and survival of OLGs, much like BDNF [54]. Up to adulthood, homozygous CNTF-KO animals have lower OPC numbers and less myelination [55].

However, in adult species, this phenotype is found only after injury is introduced. Radial glial proliferation and neurogenesis were also found to be decreased in the hippocampus of KO animals, according to another injury study [56]. The delayed maturation of particular glial forms in the CNS can therefore be caused by CNTF deficiency.

Müller glial, the most abundant type of glial cell in the retina, originates locally and is responsible for the structural, nourishment, and metabolic support of retinal neurons. Though not supported by KO models, CNTF can enhance their genesis. Most glial populations in the retina (microglia, OLGs, astrocytes) migrate from the optic nerve, except for Müller glial. For this reason, it is important to point out that the expression of NTFs in the CNS will directly correlate with the retinal glial network. 
Table 1 Effects of exogenous NTF administration on glia in injury and disease models.

\begin{tabular}{|c|c|c|c|c|c|}
\hline NTF & Disease Model & $\begin{array}{l}\text { Vector + Administration } \\
\text { (site, time) }\end{array}$ & $\begin{array}{l}\text { Glial cell } \\
\text { type }\end{array}$ & Effects on glial & References \\
\hline CNTF & SCI & $\begin{array}{l}\text { CNTF nanospheres } \\
\text { injected to lesion site } 7 \mathrm{~d} \\
\text { post - surgery }\end{array}$ & Astrocyte & $\begin{array}{l}\text { Increased reactivity in } \\
\text { contralateral gray matter on } 7 \\
\text { d after injection. } \\
\text { Not enhanced long - term } \\
\text { survival on } 4 \text { weak after CNTF - } \\
\text { injection. }\end{array}$ & $\begin{array}{l}{[57]} \\
{[57]}\end{array}$ \\
\hline NGF & $\begin{array}{l}\text { Mechanical } \\
\text { injury to sciatic } \\
\text { nerve }\end{array}$ & $\begin{array}{l}\text { NGF or NGF - like peptide } \\
\text { BB14 infused to spinal } \\
\text { cord } 3 \text {-10 d post-surgery. } \\
\text { NGF infused to spinal cord } \\
7-14 \text { d post - surgery. }\end{array}$ & $\begin{array}{l}\text { Astrocyte } \\
\text { Microglia } \\
\text { Astrocyte } \\
\text { Microglia }\end{array}$ & $\begin{array}{l}\text { NGF or BB14 reduced } \\
\text { astrocytic reactivity injury at } \\
10 \mathrm{~d} \text { post - injury. } \\
\text { NGF or BB14 attenuated } \\
\text { microglial reaction at } 10 \mathrm{~d} \text { post } \\
\text { - injury. } \\
\text { NGF attenuated astrocytic } \\
\text { reactivity and hypertrophy at } \\
14 \text { d post - injury. } \\
\text { No difference in phagocytic } \\
\text { microglia at } 14 \mathrm{~d} \text { post - injury. }\end{array}$ & $\begin{array}{l}{[58]} \\
{[58]} \\
{[59]} \\
{[59]}\end{array}$ \\
\hline BDNF & $\begin{array}{l}\text { Ischemic } \\
\text { stroke, } \\
\text { transient }\end{array}$ & $\begin{array}{l}\text { Injection in the brain upon } \\
\text { surgery } \\
\text { Intranasally } 2 \text { hour after } \\
\text { reperfusion onset ( } 4 \text { hour } \\
\text { after surgery) } \\
\text { Injection (I.V.) at } 24 \text { hours } \\
\text { after ET - } 1 \text { injection. }\end{array}$ & Microglia & $\begin{array}{l}\text { Increased microglial activation } \\
\text { and phagocytic activity at } 6- \\
24 \text { hours after reperfusion (IL- } \\
10 \text { increases, TNF }-\alpha \\
\text { decrease). } \\
\text { Increased microglial activation } \\
\text { and phagocytic activity at } 6- \\
24 \text { hours after reperfusion (IL- } \\
10 \text { increases, TNF - } \alpha \\
\text { decrease). } \\
\text { Increased proliferation in SVZ } \\
\text { on } 7 \text { d after BDNF injection and } \\
\text { maturation in lesion area on } 28 \\
\text { d, restored myelin integrity. }\end{array}$ & [61] \\
\hline GDNF & SCI & $\begin{array}{l}\text { Injection upon surgery to } \\
\text { spinal cord. } \\
\text { Injection of GDNF - } \\
\text { nanoparticles upon } \\
\text { surgery to spinal cord. }\end{array}$ & $\begin{array}{l}\text { Microglia } \\
\text { Astrocyte } \\
\text { Microglia }\end{array}$ & $\begin{array}{l}\text { Increased phagocytic microglia } \\
\text { in the spinal cord at } 1 \text { weak } \\
\text { post-injury. } \\
\text { Not affected astrocyte. } \\
\text { Not affected microglial } \\
\text { reactivity. }\end{array}$ & $\begin{array}{l}{[64]} \\
{[64]}\end{array}$ \\
\hline MANF & $\begin{array}{l}\text { Ischemic } \\
\text { stroke, } \\
\text { transient }\end{array}$ & $\begin{array}{l}\text { AAV7 - MANF } \\
\text { intracerebral injection } 2 \mathrm{~d} \\
\text { post - injury }\end{array}$ & Microglia & $\begin{array}{l}\text { Increased the number of } \\
\text { phagocytic microglia in the peri } \\
\text { - infarct region at } 4 \mathrm{~d} \text {. }\end{array}$ & [65] \\
\hline NT -3 & $\begin{array}{l}\text { MS } \\
\text { Mechanical } \\
\text { injury in optic } \\
\text { nerve }\end{array}$ & $\begin{array}{l}\text { Injection upon injury to } \\
\text { corpus callosum. } \\
\text { Intravitreal injection upon } \\
\text { surgery. }\end{array}$ & $\begin{array}{l}\text { OLG } \\
\text { Microglia }\end{array}$ & $\begin{array}{l}\text { Increased mature } \\
\text { oligodendrocytes at } 15 \mathrm{~d} \\
\text { Decreased microglial } \\
\text { activation on } 7 \mathrm{~d} \text { in the nerve } \\
\text { fiber layer. }\end{array}$ & $\begin{array}{l}{[66]} \\
{[67]}\end{array}$ \\
\hline
\end{tabular}

\section{Conclusion}

In addition to having a passive and supporting role, it is increasingly clear that glial cells often make other important contributions to the CNS, which are necessary for brain homeostasis, growth, and functions, and also participate in a 
variety of neurological diseases. Glial cell study, however, has been hindered by a series of challenges including difficulties in cultivating them in vitro, restricted accessibility of human neural tissues, altered features by the isolation method, and insufficiency of rodent animals in modeling human diseases involving glial cells due to the significant differences in morphology, function, and cell type distributors.

Maybe the reconsideration of the value of glial in neuropathology would be the key development in the near future. The neurocentric view has been questioned and it is starting to understand the understudy of neuroglia. It remains, however, that glial science, compared to that on neurons, is just a drop in the ocean. Glioma pathology is varied and nuanced and is usually characterized frequently in combination and in a disease-specific way, by degeneration, a loss of important homeostatic functions and pathological remodelling. At the early stages of neurodegenerative disorders, degenerative changes in astrocytes and oligodendrocytes are identified and are the leading morphological changes in major psychiatric diseases and in brain ageing. Microglia plays a part in these events in childhood, but its operation dictates the overall neuroprotective or neurodestructive status of the CNS, and improvements in the immune system of the brain are related to the aging of the human brain. Glial cells' true potential as therapeutic targets are largely untapped. It may be an overstatement to say that the failure in the last 100 years to cure neurodegenerative diseases is because most researchers have been looking in the wrong direction, but for sure, for another 100 years, we cannot afford to ignore nerve glue.

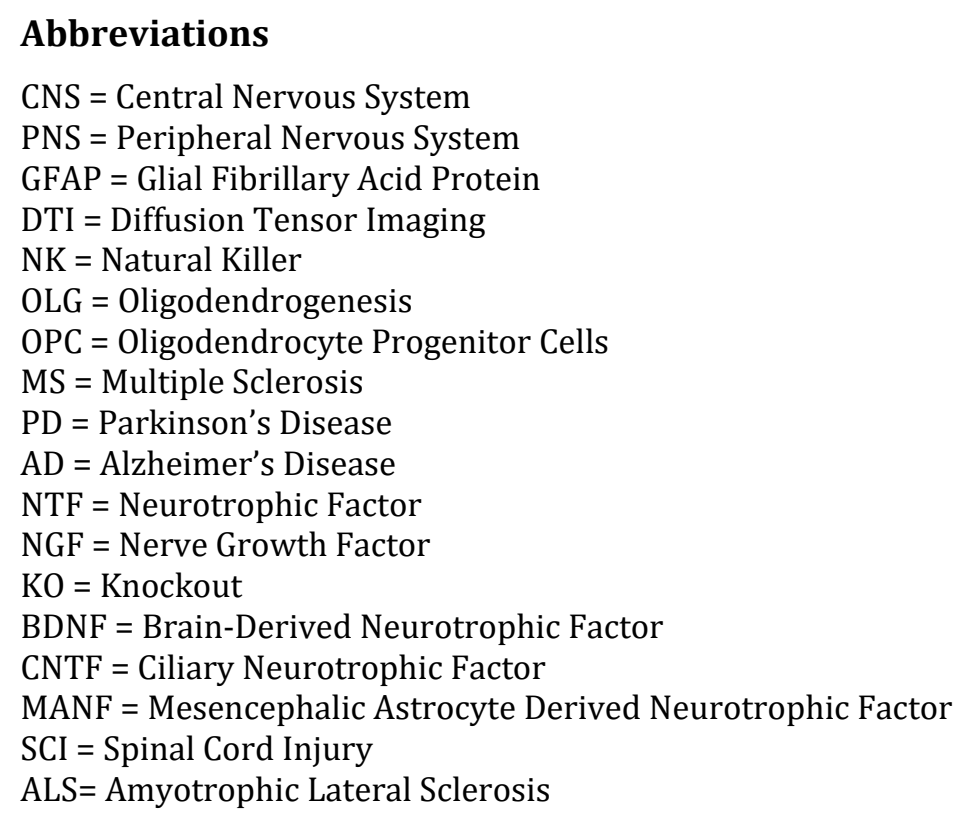

\section{Compliance with ethical standards}

\section{Acknowledgments}

The authors sincerely thank and acknowledge the administration of Dr. Baba Saheb Ambedkar Hospital for their valuable guidance and suggestions in completion of this article.

\section{Disclosure of conflict of interest}

The authors declare no conflict of interest.

\section{References}

[1] Verkhratsky and Butt. 2013.

[2] Halassa MM, Fellin T, Haydon PG. The tripartite synapse: roles for gliotransmission in health and disease. Trends Mol Med. 2007; 13: 54-63.

[3] Sofroniew MV, Vinters HV. Astrocytes: biology and pathology. Acta Neuropathol. 2010; 119: 7-35. 
[4] Seifert G, Schilling K, Steinhauser C. Astrocyte dysfunction in neurological disorders: a molecular perspective. Nat Rev Neurosci. 2006; 7: 194-206.

[5] Altshuler LL, Abulseoud OA, Foland-Ross L, Bartzokis G, Chang S, Mintz J, et al. Amygdala astrocyte reduction in subjects with major depressive disorder but not bipolar disorder. Bipolar Disord. 2010; 12: 541-9.

[6] Feresten AH, Barakauskas V, Ypsilanti A, Barr AM, Beasley CL. Increased expression of glial fibrillary acidic protein in prefrontal cortex in psychotic illness. Schizophr Res. 2013; 150(1): 252-7.

[7] Rajkowska G, Stockmeier CA. Astrocyte pathology in major depressive disorder: insights from human postmortem brain tissue. Curr Drug Targets. 2013; 14(11): 1225-36.

[8] Cao X, Li LP, Wang Q, Wu Q, Hu HH, Zhang M, et al. Astrocyte-derived ATP modulates depressive-like behaviors. Nat Med. 2013; 19: 773-7.

[9] Quesseveur G, David DJ, Gaillard MC, Pla P, Wu MV, Nguyen HT, et al. BDNF over expression in mouse hippocampal astrocytes promotes local neurogenesis and elicits anxiolytic-like activities. Transl Psychiatry. 2013; 3: e253.

[10] Hashioka S. Antidepressants and neuroinflammation: can antidepressants calm glial rage down?Mini Rev Med Chem. 2011; 11: 555-64.

[11] Hisaoka K, Tsuchioka M, Yano R, Maeda N, Kajitani N, Morioka N, et al. Tricyclic antidepressant amitriptyline activates fibroblast growth factor receptor signaling in glial cells: involvement in glial cell line-derived neurotrophic factor production. J Biol Chem. 2011; 286: 21118-28.

[12] Kajitani N, Hisaoka-Nakashima K, Morioka N, Okada-Tsuchioka M, Kaneko M, Kasai M, et al. Antidepressant acts on astrocytes leading to an increase in the expression of neurotrophic/growth factors: differential regulation of FGF-2 by noradrenaline. PLoS One. 2012; 7: e51197.

[13] Kittel-Schneider S, Kenis G, Schek J, Van Den Hove D, Prickaerts J, Lesch KP, et al. Expression of monoamine transporters, nitric oxide synthase 3, and neurotrophin genes in antidepressant-stimulated astrocytes. Front Psychiatry. 2012; 3: 33.

[14] Steiner J, Bogerts B, Sarnyai Z, Walter M, Gos T, Bernstein HG, et al. Bridging the gap between the immune and glutamate hypotheses of schizophrenia and major depression: potential role of glial NMDA receptor modulators and impaired blood-brain barrier integrity. World J Biol Psychiatry. 2012; 13: 482-92.

[15] Sanacora G, Banasr M. From pathophysiology to novel antidepressant drugs: glial contributions to the pathology and treatment of mood disorders. Biol Psychiatry. 2013; 73: 1172-9.

[16] Micu I, Ridsdale A, Zhang L, Woulfe J, Mcclintock J, Brantner CA, et al. Real-time measurement of free Ca2+ changes in CNS myelin by two-photon microscopy. Nat Med. 2007; 13: 874-9.

[17] Yamazaki Y, Hozumi Y, Kaneko K, Sugihara T, Fujii S, Goto K, et al. Modulatory effects of oligodendrocytes on the conduction velocity of action potentials along axons in the alveus of the rat hippocampal CA1 region. Neuron Glia Biol. 2007; 3: 325-34.

[18] Tkachev D, Mimmack ML, Ryan MM, Wayland M, Freeman T, Jones PB, et al. Oligodendrocyte dysfunction in schizophrenia and bipolar disorder. Lancet. 2003; 362: 798-805.

[19] McCullumsmith RE, Gupta D, Beneyto M, Kreger E, Haroutunian V, Davis KL, et al. Expression of transcripts for myelinationrelated genes in the anterior cingulate cortex in schizophrenia. Schizophr Res. 2007; 90: 15-27.

[20] Uranova NA, Vostrikov VM, Orlovskaya DD, Rachmanova VI. Oligodendroglial density in the prefrontal cortex in schizophrenia and mood disorders: a study from the Stanley Neuropathology Consortium. Schizophr Res. 2004; 67: 269-75.

[21] Uranova NA, Vostrikov VM, Vikhreva OV, Zimina IS, Kolomeets NS, Orlovskaya DD. The role of oligodendrocyte pathology in schizophrenia. Int J Neuropsychopharmacol. 2007; 10: 537-45.

[22] Bernstein HG, Steiner J, Bogerts B. Glial cells in schizophrenia: pathophysiological significance and possible consequences for therapy. Expert Rev Neurother. 2009; 9: 1059-71.

[23] Price SJ, Jena R, Burnet NG, Hutchinson PJ, Dean AF, Pena A, et al. Improved delineation of glioma margins and regions of infiltration with the use of diffusion tensor imaging: an image-guided biopsy study. AJNR Am J Neuroradiol. 2006; 27: 1969-74. 
[24] Schlosser RG, Nenadic I, Wagner G, Gullmar D, Von Consbruch K, Kohler S, et al. White matter abnormalities and brain activation in schizophrenia: a combined DTI and fMRI study. Schizophr Res. 2007; 89: 1-11.

[25] Miyata J, Hirao K, Namiki C, Fujiwara H, Shimizu M, Fukuyama H, et al. Reduced white matter integrity correlated with corticosubcortical gray matter deficits in schizophrenia. Schizophr Res. 2009; 111: 78-85.

[26] Kubota M, Miyata J, Yoshida H, Hirao K, Fujiwara H, Kawada R, et al. Age-related cortical thinning in schizophrenia. Schizophr Res. 2011; 125: 21-9.

[27] Kubota M, Miyata J, Sasamoto A, Sugihara G,Yoshida H, Kawada R, et al. Thalamocortical disconnectionin the orbitofrontal region associated with cortical thinning in schizophrenia. JAMA Psychiatry. 2013; 70: 12-21.

[28] Block ML, Zecca L, Hong JS. Microglia-mediated neurotoxicity: uncovering the molecular mechanisms. Nat Rev Neurosci. 2007; 8: 57-69.

[29] Hanisch UK, Kettenmann H. Microglia: active sensor and versatile effector cells in the normal and pathologic brain. Nat Neurosci. 2007; 10: 1387-94.

[30] Graeber MB, Streit WJ. Microglia: biology and pathology. Acta Neuropathol. 2010; 119: 89-105.

[31] Inoue K, Tsuda M. Microglia and neuropathic pain. Glia. 2009; 57: 1469-79.

[32] Kettenmann H, Hanisch UK, Noda M, Verkhratsky A. Physiology of microglia. Physiol Rev. 2011; 91: 461-553.

[33] Attwell D, et al. Glial and neuronal control of brain blood flow. Nature. 2010; 468(7321): 232-243.

[34] Khakh BS, Sofroniew MV. Diversity of astrocyte functions and phenotypes in neural circuits. Nat Neurosci. 2015; 18(7): 942-952.

[35] Sofroniew MV. Astrocyte barriers to neurotoxic inflammation. Nat Rev Neurosci. 2015; 16(5): $249-263$.

[36] Liu Z, et al. Beneficial effects of gfap/vimentin reactive astrocytes for axonal remodeling and motor behavioral recovery in mice after stroke. Glia. 2014; 62(12): 2022-2033.

[37] Li L, et al. Protective role of reactive astrocytes in brain ischemia. J Cereb Blood Flow Metab. 2008; 28(3): 468481.

[38] Wang W, et al. Rat focal cerebral ischemia induced astrocyte proliferation and delayed neuronal death are attenuated by cyclin-dependent kinase inhibition. J Clin Neurosci. 2008; 15(3): 278-285.

[39] Fang SH, et al. Increased expression of cysteinyl leukotriene receptor-1 in the brain mediates neuronal damage and astrogliosis after focal cerebral ischemia in rats. Neuroscience. 2006; 140(3): 969-979.

[40] Liu Z, Chopp M. Astrocytes, therapeutic targets for neuroprotection and neurorestoration in ischemic stroke. Prog Neurobiol. 2016; 144: 103-120.

[41] Li M, et al. Astrocyte-derived interleukin-15 exacerbates ischemic brain injury via propagation of cellular immunity. Proc Natl Acad Sci USA 2017.

[42] Waldmann TA, Tagaya Y. The multifaceted regulation of interleukin-15 expression and the role of this cytokine in NK cell differentiation and host response to intracellular pathogens. Annu Rev Immunol. 1999; 17: 19-49.

[43] Kokaji AI, Hockley DL, Kane KP. IL-15 transpresentation augments CD8+ T cell activation and is required for optimal recall responses by central memory CD8+ T cells. J Immunol. 2008; 180(7): 4391-4401.

[44] Ransohoff\& Brown. 2012.

[45] Nimmerjahn, Kirchhoff, \&Helmchen. 2005.

[46] Davalos et al. 2005; Kreutzberg. 1996.

[47] Norden, Trojanowski, Villanueva, Navarro, \& Godbout 2016; Saijo et al. 2009.

[48] Liddelow\& Barres. 2015.

[49] Kassmann et al. 2007.

[50] Zeis, Enz, \&Schaeren-Wiemers. 2016.

[51] Tang, DG, Tokumoto YM, Raff MC. Long-term culture of purified postnatal oligodendrocyte precursor cells: evidence for an intrinsic maturation program that plays out over months. J. Cell Biol. 2000; 148: 971-984. 
[52] Wheeler NA, Fuss B. Extracellular cues influencing oligodendrocyte differentiation and (re)myelination. Exp. Neurol. 2016; 283: 512-530.

[53] Crowley C, Spencer SD, Nishimura MC, Chen KS, Pitts-Meek S, Armanini, MP, et al. Mice lacking nerve growth factor display perinatal loss of sensory and sympathetic neurons yet develop basal forebrain cholinergic neurons. Cell. 1994; 76: 1001-1011.

[54] Leferink PS, Heine VM. The healthy and diseased microenvironments regulate oligodendrocyte properties: implications for regenerative medicine. Am. J. Pathol. 2018; 188: 39-52.

[55] Barres BA, Burne JF, Holtmann B, Thoenen H, Sendtner M, Raff MC. Ciliary neurotrophic factor enhances the rate of oligodendrocyte generation. Mol. Cell. Neurosci. 2016; 8: 146-156.

[56] Muller S, Chakrapani BP, Schwegler H, Hofmann HD, Kirsch M. Neurogenesis in the dentate gyrus depends on ciliary neurotrophic factor and signal transducer and activator of transcription 3 signaling. Stem Cells. 2009; 27: 431-441.

[57] Talbott JF, Cao Q, Bertram J, Nkansah M, Benton RL, Lavik E et al. CNTF promotes the survival and differentiation of adult spinal cord-derived oligodendrocyte precursor cells in vitro but fails to promote remyelination in vivo. Exp. Neurol. 2007; 204: 485-489.

[58] Cirillo G, Bianco MR, Colangelo AM, Cavaliere C, Daniele DL, Zaccaro L et al. Reactive astrocytosis-induced perturbation of synaptic homeostasis is restored by nerve growth factor. Neurobiol. Dis. 2011; 41: 630-639.

[59] Cirillo G, Cavaliere C, Bianco MR, De Simone A, Colangelo AM, Sellitti, S, et al. Intrathecal NGF administration reduces reactive astrocytosis and changes neurotrophin receptors expression pattern in a rat model of neuropathic pain. Cell. Mol. Neurobiol. 2010; 30: 51-62.

[60] Xu G, Jiang Y, Wei N, Zhu J, Lu T, Chen Z, et al. Effects of brainderived neurotrophic factor on local inflammation in experimental stroke of rat. Mediators Inflamm. 2010; 372-423.

[61] Jiang Y, Wei N, Lu T, Zhu J, Xu G, Liu X. Intranasal brain-derived neurotrophic factor protects brain from ischemic insult via modulating local inflammation in rats. Neuroscience. 2011; 172: 398-405.

[62] Ramos-Cejudo J, Gutiérrez-Fernández M, Otero-Ortega L, Rodríguez-Frutos B, Fuentes B, Vallejo-Cremades MT, et al. Brain-derived neurotrophic factor administration mediated oligodendrocyte differentiation and myelin formation in subcortical ischemic stroke. Stroke. 2015; 46: 221-228.

[63] Chang YP, Fang KM, Lee TI, Tzeng SF. Regulation of microglial activities by glial cell line derived neurotrophic factor. J. Cell. Biochem. 2006; 97: 501-511.

[64] Wang YC, Wu YT, Huang HY, Lin HI, Lo LW, Tzeng SF et al. Sustained intraspinal delivery of neurotrophic factor encapsulated in biodegradable nanoparticles following contusive spinal cord injury. Biomaterials. 2008; 29: 4546-4553.

[65] Mätlik K, Anttila JE, Kuan-Yin T, Smolander OP, Pakarinen E, Lehtonen L et al. Poststroke delivery of MANF promotes functional recovery in rats. Sci. Adv. 2018; 4: eaa8957.

[66] Jean I, Lavialle C, Barthelaix-Pouplard A, Fressinaud C. Neurotrophin-3 specifically increases mature oligodendrocyte population and enhances remyelination after chemical demyelination of adult rat CNS. Brain Res. 2003; 972: 110-118.

[67] Sobrado-Calvo P, Vidal-Sanz M, Villegas-Pérez MP. Rat retinal microglial cells under normal conditions, after optic nerve section, and after optic nerve section and intravitreal injection of trophic factors or macrophage inhibitory factor. J. Comp. Neurol. 2007; 501: 866-878.

[68] Meaghan Roy-O'Reillya and Louise D. McCullough, Astrocytes fuel the fire of lymphocyte toxicity after stroke, 2017, doi :10.1073/pnas.1619813114.

[69] Yang Qiaoqiao and Jiawei Zhou, Neuroinflammation in the central nervous system: Symphony of glial cells, 2020, DOI: 10.1002/glia.23571.

[70] Suvi Pöyhönen, Safak Er, Andrii Domanskyi and Mikko Airavaara, Effects of Neurotrophic Factors in Glial Cells in the Central Nervous System: Expression and Properties in Neurodegeneration and Injury, 2019, doi: 10.3389/fphys.2019.00486. 